\title{
衝撃波の腎に対する影響についての実験的研究
}

\begin{tabular}{llllllll}
\multicolumn{8}{c}{ 大阪市立大学医学部泌尿器科学教室 (主任：前川正信教授） } \\
飯盛 宏記 & 千住 & 将明 & 杉本 & 俊門 杉村 & 一誠 \\
山本 & 啓介 & 岸本 & 武利 & 前川 & 正信 & &
\end{tabular}

\section{SIDE EFFECTS OF EXTRACORPOREAL SHOCK-WAVE EXPOSURE ON THE KIDNEY OF DOGS}

\author{
Hiroki Iimori, Masaaki Senjyu, Toshikado Sugimoto, Kazunobu Sugimura, \\ Keisuke Yamamoto, Taketoshi Kishimoto and Masanobu Maekawa \\ Department of Urology, Osaka City University Medical School \\ (Director: Prof. Masanobu Maekawa)
}

The effects of extracorporeal shock-wave (SW) exposure on the kidney were investigated in dogs using a Dornier kidney lithotriptor HM3. The SW was generated by spark dischrge at $20 \mathrm{KV}$ and was focussed on the lower part of either kidney. Before and after the exposure of 500 and 1000 shots of SW, the renal blood flow of the affected and contralateral kidney was measured by the microsphere method. The blood flow of the affected kidney decreased, but was comparable to that of the contralateral kidney immediately after the 1000 shots of SW. Renal scintigraphy using ${ }^{99 \mathrm{~m}} \mathrm{Tc}$-DTPA was performed before the exposure of SW, and 30 minutes, 1 week, 2 weeks and 4 weeks after the exposure. The renograms were evaluated by the following parameters: $T_{\max }$ (time required to reach maximum radioactivity), $\mathrm{RA}_{\max }$ ratio (maximum radioactivity of the affected kidney/that of the contralateral kidney) and $\mathrm{T}_{1 / 2}$ (the half-life of elimination). $\mathrm{T}_{\max }$ was significantly prolonged for the affected kidney 30 minutes after the exposure, while that for the contralateral kidney was shortened. The $\mathrm{RA}_{\max }$ ratio was decreased 1 week after the exposure. $T_{1 / 2}$ was significantly prolonged 30 minutes after the exposure, which was observed till 2 weeks later. The scintigraphy also showed a slight enlargement of affected site. The histological study showed a hemorrhage in the peritubular space, indicating rupture of the peritubular capillaries. In conclusion, the main effect of SW exposure on the kidney was the rupture of the peritubular capillaries, resulting in temporary and reversible deterioration of renal function.

Key words: extracorporeal shock-wave, side effects, the kidney of a dog

要旨：ESWLは，広く臨床で用いられているが，衝撃波（SW）の生体に対する影響は皆無ではない。 著者らは，実験動物として犬を用いて，以下の実験を行った. 実験 $1 . S W$ の腎血流動態におよぼす影響 についてーmicrosphere 法により, SW 照射前,一側腎に500回照射後, 1,000回照射後の 3 回, 腎血流量 を測定した。腎血流量は，両側とも SW 照射前に比べ500回照射後に増加傾向を示し，500回照射後に比 べ1,000回照射後に減少傾向を示したが，いずれも有意の変化ではなかった。㬰験 $2 . S W$ の腎機能に拉 よぼす影響についてー99mTc-DTPA を用いたレノシンチグラフィを SW 照射前，一側腎に1,000回照射 後30分， 1 週間， 2 週間， 4 週間に行った。 tracer 静注後より，放射活性が最高值に達するまでの時間 は，30分後照射側で有意に延長し，対側で有意に短縮した。放射活性の最高值の比 (照射側/対側) は 1 週後に有意に減少した。半減期は，30分後照射側で有意に延長し，この変化は 2 週後まで続いた。 シン チグラムでは, 30分後で照射側腎の拡大を認めた。実験 $3 . \mathrm{SW}$ の腎組織におよぼす影響について一SW 500 回照射直後（A 腎）および 1 週後（B 腎），SW 1,000回照射直後（C 腎）および 1 週後（D 腎）につ いて，光学顕微鏡による組織観察を行った． A 腎 C 腎とも尿細管周囲と管腔内への出血を認めたが， B 腎 D腎にはこれらの変化を認めなかった。以上より SW の腎に拉よぼす影響は, 形態学的に出血・浮腫 が考えられ，腎機能は一時的に低下するが可逆的なものであると考えられた。 キーワード：体外衝撃波, 副作用, 犬腎 


\section{I. 緒 言}

Chaussy ら 1 の考案による体外式衝撃波尿路結石破 砕術 (ESWL) は, 最も生体侵襲の少ない上部尿路結 石治療法として全世界に普及し, 数多くの良好な成績 が報告されている2 ${ }^{2) 6)}$. しかし, ESWL 後には肉眼的血 尿, 衝撃波 (以下 $\mathrm{SW}$ と略す) 射入部拈よび身出部の 皮下出血がしばしば観察され, CPK, aldolase, LDH, GOT, GPT などの血中酵素の上昇, T-Bil, free hemoglobinの上昇などが報告されている(6) 8). また, 頻度は

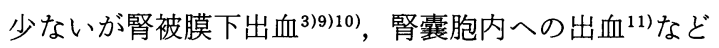
の合併症の報告があり, SW の生体におよぼす影響は, 全く無ではない, そこで, 著者らは, SW の特に腎臓に およぼす影響, すなわち，1）腎血流動態におよぼす影 響，2）腎機能におよぼす影響，3）腎臓の組織におよ ぼす影響を知るため三つの実験を行った。

\section{II. 実験方法}

\section{1. 実験動物ならびに方法}

雑種成犬 19 頭（体重 $12.7 \pm 0.32 \mathrm{~kg}$ ）を上記 3 実験に 用いた。 Pentobarbital sodium $(30 \mathrm{mg} / \mathrm{kg})$ の静脈内 投与により麻酔を行い，気管内に気管カニューレを挿 入し、レスピレーター（R-60, Aika 製)により呼吸管 理を行った. 右前肢の皮静脈に，薬剂投与用に血管内 留置針（NIC-20，ニプロ製）を留置し，生理食塩水を $60 \mathrm{ml} / \mathrm{hr}$ で点滴静注した。ついで, 衝撃波破砕装置 （Kidney lithotriptor type HM3，Dornier 製）の懸架 台に，犬を背位に固定し浴槽の中にいれ，腎蔵の呼吸 性移動を軽減させ出来るだけ SW 腎臓の同一部位 に照射させるため, レスピレーターを HFO jet ventilator (AE-20メラ製) に変方高頻度人工呼吸法 ${ }^{12}$ （駆 動圧 $1 \mathrm{~kg} / \mathrm{cm}^{2}$, 換気回数 1 秒間 4 回, 吸息相 : 呼息相 $=$ 1：2)を行い, 造影剂(60\%ウログラフィン, シェー リング製) $20 \mathrm{ml}$ を静脈内投与した後, $\mathrm{SW}$ を電圧 $20 \mathrm{KV}$ で一側腎下半部に照射した。

2. 腎血流動態におよぼす影響について一実験 1 -

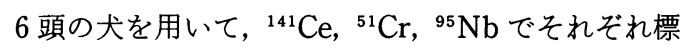
識した carbonized microsphere $(\phi 15 \pm 3 \mu \mathrm{m}$, New England Nuclear製）を用いた microsphere method $^{1314)}$ とより, SW 照射前, SW 500回照射後, 及 び1,000回照射後の 3 回, 心拍出量及び藏器血流量を測 定した。 3 回目の測定終了後, 臓器一部を摘出し贜器 sample とした. 腎蔵は両側全摘出し水平面で二等分し た. 各核種の microsphere の注入量を表すスタンダー ド，および各 sample の放射活性をガンマカウンター (Packard auto gamma scintillation spectrometer
Fig. 1 Formula for calculating cardiac output $(\mathrm{ml} / \mathrm{min})$ and blood flow per $\mathrm{g}$ of organ weight $(\mathrm{ml} / \mathrm{min} \cdot \mathrm{g})$

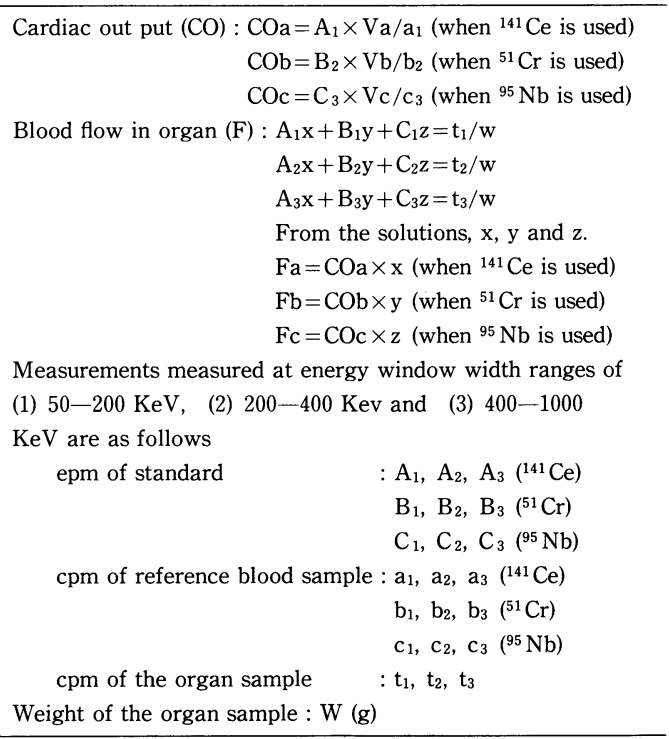

5320）にて，測定エネルギーwindow width， 50２00 $\mathrm{KeV}$ (1), $200 \sim 400 \mathrm{KeV}$ (2), $400 \sim 1,000 \mathrm{KeV}$ (3)の 設定下に同時に測定し, Fig. 1 に示した計算式によ り, 心拍出量 $(\mathrm{ml} / \mathrm{min})$ 拉よび臟器 $1 \mathrm{~g}$ あたりの血流量 $(\mathrm{ml} / \mathrm{min} \cdot \mathrm{g})$ を算出した。

3.レノシンチグラフィによる腎機能におよぼす影 響について一実験 2 -

9 頭の犬を用いて, ${ }^{99 \mathrm{~m} T c-D T P A}$ (diethylene triamine penta acetic acid) ${ }^{15)}$ 用いたレノシンチグ ラフィを, 同一犬について SW 照射前, 前述之同様の 方法で $\mathrm{SW}$ を $20 \mathrm{KV} て ゙ 1,000$ 回左堅下半部に照射後 30 分, 1 週間, 2 週間, 4 週間に行った。腹位にて, 低 エネルギー, 高分解能コリメーターを装着したシンチ カメラ (シグマ410S, Technicare 製) を背面に置き, $10 \mathrm{mCi}$ の $^{99 \mathrm{~m}} \mathrm{Tc}$-DTPA を bolus で静脈内投与した. 投 与と同時に, $64 \times 64$ の matrix で最初の 1 分間は 1 秒 毎, その後 20 秒毎 135 フレームの, データをデータ処理 装置 (Simis 4, Sopha medical 製)に収集, 処理した. 関心領域は, 左右両腎全体および左右両腎のそれぞれ 上半部と下半部の 6 領域とし, background は, 右腎下 方で膀胱にかからない部位とした。をた，5分毎に， シンチグラムを撮像した。得られたレノグラムよ り, ${ }^{99 \mathrm{~m}} \mathrm{~T} \mathrm{c}-\mathrm{DTPA}$ 静注開始時点から放射活性が最高値 に達するまでの時間（Tmax）, 放射活性の最高値 
Fig. 2 A : Scintigram ( ${ }^{99 m}$ Tc-DTPA) 30 minutes after extracorpreal shock wave discharge. B: Renogram ( ${ }^{99 m}$ Tc-DTPA) 30 minutes after extracorpreal shock wave discharge.

A
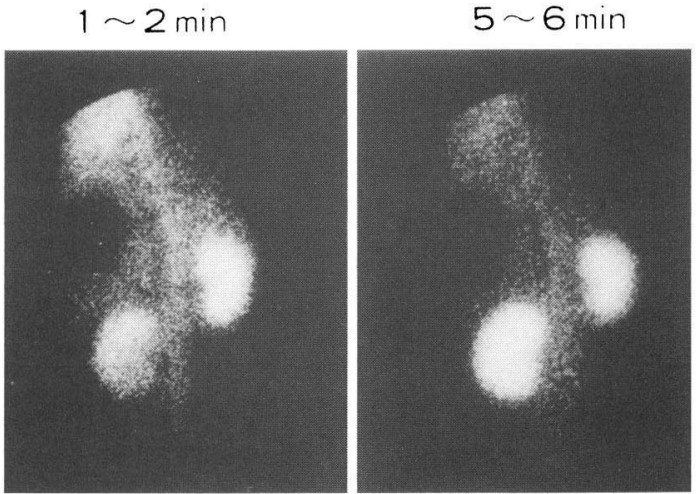

$10 \sim 11 \mathrm{~min}$

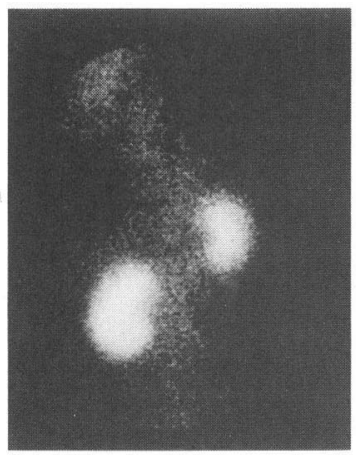

$25 \sim 26 \min$

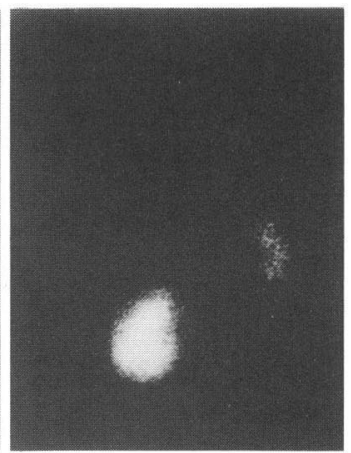

B
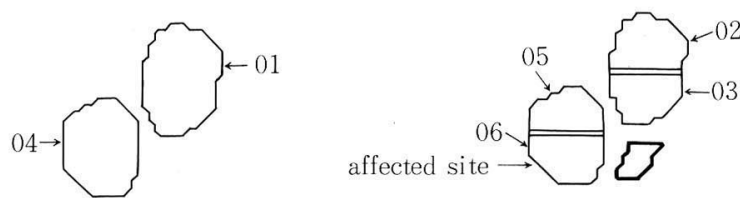

${ }^{\wedge} 5 / 29 / 37$ DOC29 (POST ESHL)

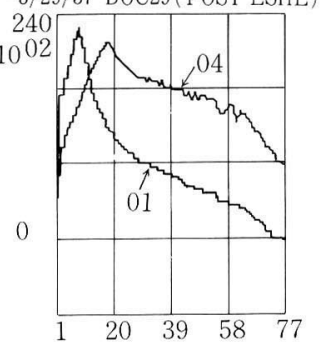

MEAM-E.C

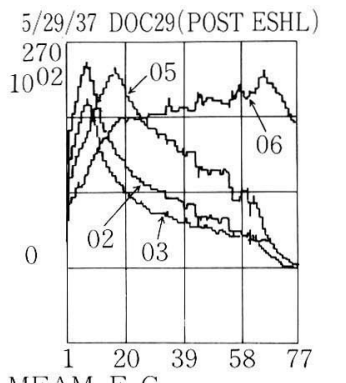

MEAM-E.C

(Rmax)の比 (照射側/対側), 放射活性の半減期 (T1)

2）を求めて, 比較検討した。
4.腎臓の組織におよぼす影響を知るための実験 一実験 3 -

SW 照射直後, 1 週間の腎臓について, 光学顕微鏡に よる組織学的検討を行った。前述と同様の方法で, SW を左腎下半部に電圧 $20 \mathrm{KV}$ で500回または1,000回照射 し，それぞれ照射直後あるい:照射 1 週後に腎臓を摘 出した。ホルマリン固定の後, hematoxylin eosin 染色 (HE 染色) および periodic acid-Schiff 染色（PAS 染 色）による光学顕微鏡的観察を行った.

5. 統計処理

測定，算出した数値は，平均值 (mean) 及び標準䛊 差（SE）で表した。有意差検定は，paired t-testで， 危険率（P）0.05以下を有意とした。

\section{III. 実験成績}

\section{1. 実験 1}

心拍出量，血圧，心拍数に関しては，有意の変化は 観察されなかった。

Table 1 に，腎臓1g たたりの血流量を示した。血流 量は, 照射前に比較してすべての部位で500回照射後に 増加傾向を示し，1,000回照射後は500回照射後より減 少傾向を示したが，いずれも有意の変化ではなく，ま た，照射部位である左腎下半部に扎いても，他の部位 と比較して特別の変化は観察されなかった。

他臓器（肝, 脾, 筋, 結腸) の $100 \mathrm{~g}$ あたりの血流量 では, 左腎近接部の下行結腸以外の臓器においては, 有意の変化は観察されなかった。しかし，左腎近接部 の下行結腸に扣いては, 照射前に比較して500回照射後 に血流量は減少し，1,000回照射後は更に減少し，これ は，有意（p<0.05）の変化であった。

\section{2. 実験 2}

Fig. 2A に SW 照射30分後の腎シンチグラム，Fig.

Table 1 Change of renal blood flow $(\mathrm{ml} / \mathrm{g} \cdot \mathrm{min})$ pre-and postextracorporeal shock wave discharge. $(\mathrm{n}=6)$

\begin{tabular}{ll|c|c|c}
\hline & & pre & $\begin{array}{c}\text { after } \\
500 \mathrm{SW}\end{array}$ & $\begin{array}{c}\text { after } \\
1000 \mathrm{SW}\end{array}$ \\
\hline involved & whole & $4.62 \pm 0.62$ & $6.29 \pm 0.32$ & $4.99 \pm 0.35$ \\
involved & upper half & $4.7 \pm 0.73$ & $6.28 \pm 0.33$ & $5.07 \pm 0.38$ \\
involved & lower half* & $4.55 \pm 0.51$ & $6.31 \pm 0.35$ & $4.92 \pm 0.36$ \\
contralateral & whole & $5.54 \pm 0.61$ & $6.83 \pm 0.35$ & $5.34 \pm 0.24$ \\
contralateral & upper half & $5.59 \pm 0.61$ & $6.86 \pm 0.37$ & $5.34 \pm 0.24$ \\
contralateral & lower half & $5.49 \pm 0.63$ & $6.81 \pm 0.34$ & $5.34 \pm 0.25$ \\
\hline
\end{tabular}

values are mean $\pm \mathrm{SE}$. $\mathrm{SW}$ : shock wave

* discharged portion 
Table 2 Change of time to peak (sec) pre-and postextracorporeal shock wave discharge. $(n=9)$

\begin{tabular}{lll|c|c|c|c|c}
\hline & & pre & $30 \mathrm{~min}$ after & $1 \mathrm{w}$ after & $2 \mathrm{w}$ after & $4 \mathrm{w}$ after \\
\hline raw data & Involved & whole & $160 \pm 13$ & $202 \pm 24$ & $198 \pm 19$ & $170 \pm 22$ & $140 \pm 7$ \\
& Involved & upper half & $154 \pm 13$ & $204 \pm 24$ & $167 \pm 20$ & $168 \pm 22$ & $140 \pm 7$ \\
& Involved & lower half* & $163 \pm 14$ & $222 \pm 23^{* *}$ & $211 \pm 20$ & $183 \pm 26$ & $150 \pm 9$ \\
& contralateral & whole & $151 \pm 15$ & $122 \pm 13^{* *}$ & $167 \pm 12$ & $160 \pm 20$ & $140 \pm 7$ \\
& contralateral & upper half & $143 \pm 16$ & $118 \pm 14^{* *}$ & $156 \pm 10$ & $158 \pm 19$ & $140 \pm 14$ \\
& contralateral & lower half & $157 \pm 14$ & $124 \pm 13^{* *}$ & $167 \pm 13$ & $168 \pm 24$ & $150 \pm 5$ \\
ratio & & & & & & $1.05 \pm 0.02$ & $1 \pm 0$ \\
(Involved/contralateral) & upper half & $1.1 \pm 0.04$ & $1.98 \pm 0.32^{* *}$ & $1.08 \pm 0.11$ & $1.06 \pm 0.03$ & $1.02 \pm 0.06$ \\
& & lower half & $1.04 \pm 0.03$ & $2.05 \pm 0.37^{* *}$ & $1.34 \pm 0.2$ & $1.09 \pm 0.04$ & $1 \pm 0.1$ \\
\hline
\end{tabular}

Values are means $\pm \mathrm{SE}$.

* discharged portion $\quad{ }^{* *}(\mathrm{p}<0.05)$ significant difference from the pre value. (Paired-t-test)

2B にレノグラムの一例を示した. シンチグラムでは, 照射側において, 初期相で tracer の集積遅延を認め, 排泄相では tracer の停滞を認める。また，腎の大きさ も対側に比較して拡大している。レノグラムでは, 照 射側において, Tmax の延長, Rmax の低下, T1/2の 延長を認め, これらの変化は, 照射部である左腎下半 部において特に著しい。

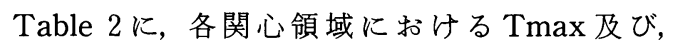
Tmaxの比(照射側/対側)を示した。Tmaxは，照射 側の下半部で, 照射 30 分後有意 $(\mathrm{p}<0.05)$ 飞延長し, 1 週後, 2 週後と時間経過とともに徐々に短縮し， 4 週後にほぼ照射前值に復した。照射側上半部において も照射 30 分後に延長傾向を示したが，有意の変化では なかった。対側においては，すべての関心領域におい て, 照射 30 分後 Tmax は有意 $(\mathrm{p}<0.05)$ に短縮したが, 1 週後には，この変化は消失していた。各関心領域に おける Tmax の比は, 照射30分後にすべての関心領域 において，有意に $(\mathrm{p}<0.05)$ 増加した。

Table 3 に各関心領域における Rmaxの比（照射 側/対側）を示した。
Rmax の比は, すべての関心領域において照射 30 分 後に，照射前に比較し低下したが，有意の变化ではな かった。腎下半部の $\mathrm{Rmax}$ は， 1 週後に，照射前に比 較して有意に低値となった。腎上半部括よび腎全体の Rmax は, 1 週後に, 30 分後に比較して増加し， 2 週 後に照射前値に復した。

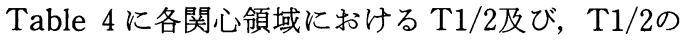
比を示した。 T $1 / 2$ は, 照射側下半部で, 照射前に比較 して照射 30 分後に有意 $(\mathrm{p}<0.01)$ に延長し, この変化 は， 1 週後， 2 週後にも認められ $(\mathrm{p}<0.05), 4$ 週後 にほぼ照射前值に復した。照射側上半部では, $\mathrm{T} 1 / 2$ は, 照射前に比較して照射 30 分後に有意 $(\mathrm{p}<0.05)$ に延長 し, 1 週後, 2 週後と時間経過とともに徐々に短縮し, 4 週後に照射前值に復した。

\section{3. 実験 3}

Fig. 3 に, SW 1,000回照射直後の腎臓の肉眼像を示 した。被膜下血腫が観察され，水平割面で $\mathrm{SW}$ 射入部 及び射出部と思われる部位に微小出血巣が，また腎髄 質層に放射状にならぶ出血巣が観察された.SW 500回 照射直後の腎臓の光学顕微鏡像では, 尿細管周囲の毛

Table 3 Change of ratio of maximum uptake (involved/contralateral) pre-and postextracorporeal shock wave discharge, $(n=9)$

\begin{tabular}{l|c|c|c|c|c}
\hline & pre & $30 \mathrm{~min}$ after & $1 \mathrm{w}$ after & $2 \mathrm{w}$ after & $4 \mathrm{w}$ after \\
\hline whole & $0.94 \pm 0.04$ & $0.70 \pm 0.12$ & $0.77 \pm 0.09$ & $0.93 \pm 0.06$ & $0.92 \pm 0.12$ \\
upper half & $0.95 \pm 0.06$ & $0.71 \pm 0.11$ & $0.89 \pm 0.08$ & $0.96 \pm 0.06$ & $0.95 \pm 0.18$ \\
lower half* $^{*}$ & $0.95 \pm 0.03$ & $0.71 \pm 0.13$ & $0.67 \pm 0.07^{* *}$ & $0.89 \pm 0.04$ & $0.87 \pm 0.1$ \\
\hline
\end{tabular}

Values are mean $\pm \mathrm{SE}$.

* lt. lower half kidney is discharged portion

** $(\mathrm{p}<0.01)$ significant difference from the pre value. (Paired-t-test) 
Table 4 Change of time from peak to half-peak height (sec) pre-and postextracorporeal shock wave discharge. $(n=9)$

\begin{tabular}{lll|c|l|l|l|l}
\hline & & pre & 30 min after & $1 \mathrm{w}$ after & $2 \mathrm{w}$ after & $4 \mathrm{w}$ after \\
\hline raw data & involved & whole & $246 \pm 36$ & $906 \pm 132^{* * *}$ & $723 \pm 117^{* *}$ & $471 \pm 72^{* *}$ & $240 \pm 51$ \\
& involved & upper half & $242 \pm 34$ & $694 \pm 140^{* *}$ & $566 \pm 91$ & $393 \pm 61$ & $230 \pm 51$ \\
& involved & lower half* & $232 \pm 35$ & $1056 \pm 128^{* * *}$ & $834 \pm 112^{* * *}$ & $553 \pm 91^{* *}$ & $285 \pm 42$ \\
& contralateral & whole & $255 \pm 34$ & $262 \pm 38$ & $294 \pm 30$ & $294 \pm 40$ & $218 \pm 29$ \\
& contralateral & upper half & $254 \pm 35$ & $293 \pm 57$ & $309 \pm 34$ & $276 \pm 40$ & $230 \pm 58$ \\
& contralateral & lower half & $247 \pm 34$ & $309 \pm 53$ & $281 \pm 34$ & $281 \pm 35$ & $245 \pm 51$ \\
ratio & & & & & & \\
(Involved/contralateral) & whole & $0.99 \pm 0.08$ & $3.64 \pm 0.38^{* * *}$ & $2.72 \pm 0.56$ & $1.21 \pm 0.43$ & $1.05 \pm 0.1$ \\
& & upper half & $1.0 \pm 0.11$ & $2.79 \pm 0.52^{* *}$ & $2.31 \pm 0.65$ & $1.84 \pm 0.64$ & $1.02 \pm 0.07$ \\
& & lower half & $0.94 \pm 0.03$ & $4.09 \pm 0.7^{* *}$ & $3.65 \pm 0.9 * *$ & $2.26 \pm 0.56$ & $1.27 \pm 0.17$ \\
\hline
\end{tabular}

Values are means $\pm \mathrm{SE}$.

${ }^{*}$ discharged portion ${ }^{* *}(\mathrm{p}<0.05),{ }^{* * *}(\mathrm{p}<0.01)$ significant difference from the pre value. (Paired-t-test)

細血管よりの出血，尿細管腔内への出血が認められ， これは特に皮髄境界から髄質深部にかけての部位で顕 著であった。一部, 繊維素の析出も認められた。また, 一部の尿細管主部上皮細胞に空胞变性が認められた. 系球体には構造上著変は認められなかった。

Fig. 4 に SW 1,000回照射直後の腎臓の光学顕微鏡 像 (A：HE染色, ×100, B : HE染色, ×400) を示し た. 500 回照射直後の腎臓に観察された所見（上述）に 加点, この際には小葉間静脈または弓状静脈からの出 血も認められ，髄質深部のみならず皮質領域にも認め られた。繊維素の析出, 尿細管主部上皮細胞の空胞変 性が認められ, 500回照射直後の腎臓 (上述) に比較し て顕著であった。糸球体には構造状著変は認められな かった。

尚, PAS 染色標本においては, 500回照射直後および 1,000回照射直後のいずれの腎葴にも, 糸球体, 尿細管 の基底膜の破綻は，認められなかった。

SW 500回照射 1 週後の腎臓の光学顕微鏡像では, 照 射直後に認められた種々の所見は認められなかった.

SW 1,000回照射 1 週後の腎臓の光学顕微鏡像におい ても同様の所見であった。

\section{IV. 考 察}

Chaussy 5 2)16) は，実験的結石犬または無処置犬に SWを500回照射し，2 週後に腎及びその近接臓器の光 学顕微鏡による組織学的検索を行い，異常所見を見い ださなかったと報告したが,これ以外は, SW の生体に 与える影響, 特に腎臓に与える影響についての基礎的 実験に関する報告は, 少ない。そこで, 著者らは, 前 述の方法を用い, SW の腎血流動態におよぼす影響, 腎
機能に抽よぼす影響，腎臓の組織におよぼす影響を調 ベた。

実験 1 において，腎血流量は SW 照射により有意の 変化ではないが増加傾向を示した.この変化の原因は, 身体が温水につかったことにより全身循環動態が変化 するのは明らかなことであり，なた他に，痛み刺激に よる影響, 換気方法による影響など, SW の影響以外に も種々の要因が考えられるので，必ずしも一元的には 説明しえないが，腎藏が SW に照射されたことによ り，(1)交感神経の緊張状態が惹起される，またその結 果，(2)循環動態に影響を抢よぼす何らかの体液因子の 分泌が惹起される,などの SW の直接作用も否定でき ない.しかし、いずれにせよ，SWの腎血流動態におよ

Fig. 3 The kidney just after extracorporeal shock wave discharge. (1,000 shock waves) Subcapsular hemorrhage is seen on the left. On the right arrows show the direction of shock wave passage.
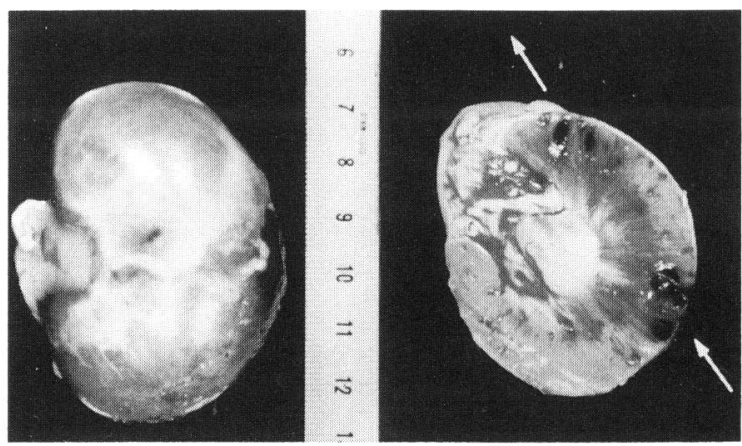
Fig. 4 The kidney just after extracorporeal shock wave discharge. (1,000 shock waves)

A $(\mathrm{HE} \times 100)$ : Interstitial hemorrhage and precipitation of fibrin are seen. $\mathrm{B}(\mathrm{HE} \times 400)$ :

Peritubular hemorrhage and vacuolation of tubular epithelial cell are seen.

A

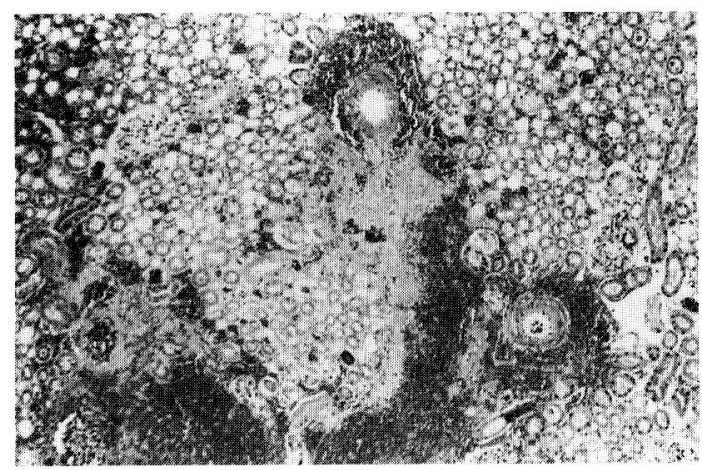

ぼす影響は，少なくとも照射中および照射直後には殆 どないと判断しえる。他藏器では, 照射側近接部の下 行結腸で，血流量が有意に減少したが，これは，管腔 臓器であるが故に, 生体と異なる音響学的インピーダ ンスを持った物質, 例党ば腸管ガスなどと接するため, SW のエネルギーが消費され，血流動態に影響を及ぼ すなんらかの機序が働いたことを示唆する。事実, 臨 床上に扮いても, ESWLの術中や術後に心窝部痛や呕 気がしばしば観察される。これに関しては, Bomanji ら ${ }^{17)}$ は, reflux autonomic response $の$ 存在を推定して いる.

${ }^{99 \mathrm{~m}} \mathrm{mTc}$-DTPA は，体内で代謝を受けず，系球体で 濾過され，尿細管で再吸収を受けない物質で，腎での 動態は, 腎血流量, 手球体濾過值, 尿排泄状態の 3 因 子により決定され，これら 3 因子による総合的な腎機 能が、レノグラム解析により推定しうる。そのための レノグラム解析の paramater は種々あるが, 一般に広 く用いられているのは, Tmax, Rmax, T1/2である ${ }^{18) .}$ この中で, Tmax は前述の 3 因子のらち腎血流量と系 球体滤過值を反映し，Rmaxは 3 因子すべてを反映 し，T1/2は主に尿排泄状態を反映すると考兄られる。 即ち, Tmax の延長は, 腎血流量の低下或は系球体濾 過値の低下を意味すると考兄られる。また，Rmaxの 低下は，T Tmax の延長と同じ意味に加党，尿排泄状態 の元進も意味すると考えられる。 また，T1/2の延長は， 尿排泄状態の低下を意味すると考兄られる．著者らの 成績によると，T $\max$ は， SW 照射後30分のレノグラ ムで照射部の左腎下半部に扔いて有意に延長し左腎上 半部においても延長傾向を示している.これは, (1) SW

\section{B}

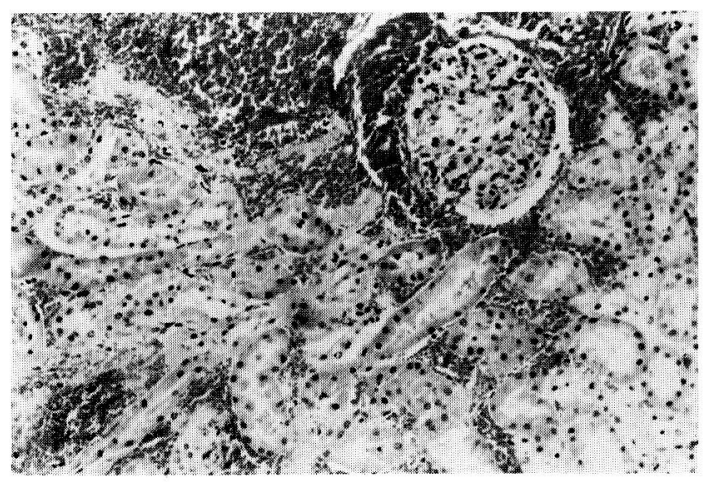

照射側腎の血流量の低下，あるいは，(2)系球体濾過値 の低下，を示唆する所見である。(1)については実験 1 の成績により, 腎血流量の低下はないことが示されて いるので, Tmax の延長の原因には主に(2)が関与して いるものと思われる。しかし, 実験 1 は, 照射直後に 施行されたのに対し，レノシンチグラフィは，30分後 に施行されたといら時間的なずれがあり，この約 30 分 の間に，腎血流量を低下させるようななんらかの機序 が働いたという可能性も否定できない，特に，Rmax が, SW 照射後 1 週後に最も低下したこと, T max の 延長が, SW 照射 1 週後も続いていたことは, この機序 の存在を強く示唆するものである。 T $1 / 2$ は, 一般に obstructed nephropathy で延長する.臨床において

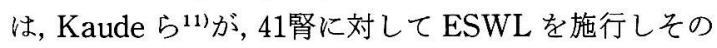
前後で, ${ }^{131}$ I-orthoiodohippurateを用いたレノシンチ グラフィを施行し, 閉塞の原因となるような結石の破 碎片は存在しないにるかかわらず2 腎に total parenchymal obstruction を認めたと報告している。この報 告とは, 用いた薬剤が異なるため, 同一レベルでは論 じ得ないが，著者らの実験犬に扔いては結石はなく， したがって結石の破碚片による閉塞は起こり得ない。 にもかかわらず T1/2は, SW 照射側すべての関心領域 で有意に延長し，しかもこの変化は, SW 照射側全体拉 よび下半部において，SW 照射 1 週後および 2 週後も 存続していた。これは，腎虚血による尿細管の水・Na の再吸収の方進 ${ }^{17}$, 浮腫による尿細管圧迫による尿流 通過障害などの, SW の直接作用の存在を示唆するも のと考党られる。

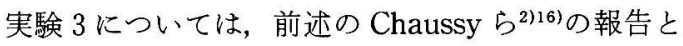


相違する結果が得られたが，これは Chaussy らが結石 に焦点を合わせ, SW 500 回照射し 1 週後に観察した のに対し, 著者らは腎臓そのものに焦点わ合わせ 1,000 回のSWを照射し，直後に観察したためと考兄られ る. 即ち本実験に抏いては, Chaussy らの実験と比較 して，腎臓に照射されるェネルギ一量が大きかったた めと考学られる。黑須ら ${ }^{199}$ は, 実験的結石犬と無処置犬 にそれぞれ200回照射と500回照射の計 4 群に分け組織 学的検討をし，4 群ともに，尿細管周囲毛細血管から の出血, 糸球体周囲からボウマン囊腔内への出血およ び尿細管腔内への出血を認め, また, これらの変化は, 1 週後には認めなかったと報告している。この組織学 的所見は，お拉むね著者の成績と一致するところであ る. 著者は，無処置犬に500回および1,000回の SW を 照射したわけであり，黒須らの報告における SW 数よ り多く, 黒須らの得た所見以外に, 間質のかなり広範 囲にわたる出血巣を認めた。従って, SW の腎組織に与 える影響の主たるものは出血であり，乙かもその程度 は, SW 照射回数の増加に従い増大するものと思われ る. また， 1 週後では異常所見を認めなかったことよ り, 組織学見地からはSW の腎臓におよぼす影響は, さほど重大ではないと考兄られる。

実験 1 において, SW 500回照射後に比較して 1,000 回照射後に腎血流量は減少傾向を示し, また, SW 照射 30分後に施行したレノグラムにおいては，腎血流量の 減少が疑われたが，これらの所見と組織学的所見を総 合的に考学ると, SW の直接作用により, 尿細管周囲の 毛細血管の破綻が惹起され，SW の照射回数が増すに つれ，小葉間静脈，弓状静脈など，毛細血管より太い 静脈まで破綻をきたして出血し，この出血により，腎 血流量を減少させるような機序が徐々に働いたと考兄 られる、また, 腎血流量の減少により尿細管吸収能が 充進した, あるいは, 出血巣による尿細管の圧迫や浮 腫による尿細管の圧迫により尿流停滞がもたらされ， T1/2が延長した。しかも, SW 照射 1 週後には, 組織 像ではこれといら異常を認めないのに尿流停滞は依然 として存続したと考兄られる。

我国に打いては, 100 人のらち約 4 人が一生の間に一 度は尿路結石症に罹患するという報告20)があり, 再発 率も高く, 同一患者が繰り返し治療を受ける場合も稀 ではない，尿路結石症の治療法は，初発例再発例を問 わず, 安全確実に治療操作が可能で, かつ反復施行の できる方法が望ましい，その意味からすれば，観血的 手術は，可及的差し控壳るべきであり，ESWLはこの
理想に近い治療法と言える。しかし，全く問題がない わけではなく, 本実験で示されたように, SW 照射によ り一時的に腎機能は低下する. 従って, 具体的な数字 は言及しえないが, 同一患者に繰り返し SWを照射す る場合には, 一回の治療に用いる SW 数及び治療間隔 に注意する必要があり, そして, 腎機能低下の認めら れる患者には, 一回の治療に用いる SW 数を多少減量 する必要があると考兄られた。

\section{V. 結 語}

犬の腎臓に SW を照射し, 腎血流量の測定, レノシ ンチグラフィならびに組織学的検討を行い, 以下の結 果を得た。

1. 心拍出量, 血圧, 心拍数に関しては, 照射前後で 有意の変化は観察されなかった。

2. 腎血流量は, SW 照射側, 対側とも500回照射後に 上昇傾向を示し，1,000回照射後は500回照射後より減 少傾向を示したが, いずれも有意の変化ではなかった.

3. SW 照射 30 分後のシンチグラムでは, 照射側腎に おける tracer の集積遅延と排泄遅延, および腎臓の拡 大を認めた。

4.レノグラムの解析では, SW 照射部位において, 照射 30 分後のレノグラムで, $\mathrm{T} \max$ の延長, $\mathrm{T} 1 / 2$ の延 長, Rmax の比 (照射側/対側) の低下を認めた。 T1/ 2 延長は, 4 週後には照射前値に回復し, Rmax の比 の低下は， 1 週後のレノグラムでもっとも低下した。

5. SW 照射直後の腎臓の肉眼的組織所見は, 腎被膜 下出血と, 腎実質内の微小出血であった.

6. SW 照射直後の腎臓の組織の光学顕微鏡的所見 は, 間質及び尿細管腔内への出血であり, その程度は 500 回照射された腎より1,000回照射された腎の方が大 であった。しかし，この変化はともに 1 週後には認め られなかった。系球体および尿細管の基底膜は, SW 照 射直後においても異常所見を示さなかった。

以上の結果より, SW の腎臓に与える影響は, 組織学 的には腎組織内の出血であり, これにより腎機能は一 時的に低下するが, 可逆的なものであると考劣られた。

本論文の要旨は, 第76回日本泌尿器科学会総会, 第28回日 本核医学会総会に招いて発表した。

稿を終えるにあたり，懇切な御指導と御校閲を賜りまし た前川正信教授と本学医動物学教室高田季久教授, ならび に始終直接御指導頂きむした岸本武利助教授, 山本啓介講 師, 杉村一誠博士, 本学 RI 研究室越智宏暢助教授に深甚な る謝意を表します。また, 病理組織像についてあたたかい御 助言をいただいた本学第一病理学教室藤本輝夫教授に深く 
感謝致します。

$$
\text { 文献 }
$$

1) Chaussy, C., Eisenberger, F., Wanner, K., Forssman, F., Hepp, W., Schmiedt, E. and Brendel, W. : The use of shock waves for the destruction of renal calculi without direct contact. Urol. Res., 4, 181, 1976.

2) Chaussy, C., Brendel, W. and Schmiedt, E. : Extracorporeally induced destruction of kidney stones by shock waves. Lancet, 2, 1265-1268, 1980.

3) Chaussy, C., Schmiedt, E., Jocham, D., Brendel, W., Forssmann, B. and Walther, V.: First clinical experience with extracorporeally induced destruction of kidney stones by shock waves. J. Urol., 127, 417-420, 1982.

4) Lingeman, J.E., Newman, D., Mertz, J.H.O., Mosbaugh, P.G., Steele, R.E., Kahnoski, R.J., Coury, T.A. and Woods, J.R. : Extracorporeal shock wave lithotripsy: The Methodist hospital of indiana experience. J. Urol., 135, 1134-1137, 1986.

5) Drach, G.W., Study Coordinator, Dretler, S., Fair, W., Finlayson, B., Gillenwater, J., Griffith, D. and Study Group.: Report of the United States cooperative study of extracorporeal shock wave lithotipsy. J. Urol., 135, 1127-1133, 1986.

6) 新島端夫, 岩動孝一郎, 梅田 隆, 岸 洋一, 東原 英二, 赤座英之, 富永登志, 藤目 真, 原徹, 木村 明, 平野美和, 鈴木 明, 平澤 潔, 吉田雅 彦, 徳田 拓, 柴本賢秀: ESWL (Extracorporeal Shock Wave Lithotripsy)の臨床経験. 日泌尿会 誌, 76, 1460-1467, 1985.

7) Kishimoto, K., Yamamoto, K., Sugimoto, T., Yoshihara, H. and Maekawa, M. : Side effects of extracorporeal shock-wavw exposure in patients treated by exracorporeal shock-wave lithotripsy for upper urinary tract stone. Eur. Urol., 12, 308-313, 1986.

8) Ruiz Marcellan, F.J. and Ibalz Servio, L. : Evaluation of renal damage in exracorporeal lithotripsy by shock waves. Eur. Urol., 12, $73-75,1986$.

9) Chaussy, C. and Schmidt, E.: Extracorporeal shock wave lithotripsy (ESWL) for kidney stones. An alternative to surgery? Urol. Radiol., 6, 80-87, 1984.
10) Papanicolou, N., Stafford, S.A., Phister, R.C., Althausen, A.F. and Dretler, S.P.: Significane renal hemorrhage following extracorporeal shock wave lithotripsy: Imaging and clininal features. Radiology, 163, 661-664, 1987.

11) Kaude, J.V., Williams, C.M., Millner, M.R., Scott, K.N. and Finalayson, B.: Renal morphology and function immediately after extracorporeal shock-wave lithotripsy. A.J.R., 145, 305-313, 1985.

12) Perel, A., Hoffman, B., Podeh, D. and Davidson, J.T.: High frequency positive pressure ventilation during general anesthesia for extracorporeal shock wave lithotipsy. Anesth. Analg., 65, 1231-1234, 1986.

13) Ishise, S., Pegram, B.L., Yamamoto, J., Kimura, Y. and Frohlich, E.D.: Reference sample microsphere method: Cardiac output and blood flows in conscious rats. Am. J. Physiol., 239, H443-H449, 1980.

14) Tsuchiya, M., Walsh, G.M. and Frohlich, E.D. : Systemic hemodynamic effects of microspheres in conscious rats. Am. J. Physiol., 233, H617-H621, 1977.

15) Hauser, W., Atkins, H.L., Nelson, K.G. and Richards, P.: Technetium-99m DTPA : A new radiopharmaceutical for brain and kidney scanning. Radiology, 94, 679-684, 1970.

16) Chaussy, C., Schmiedt, E., Jocham, D., Walther, V., Brendel, W., Forssmann, B. and Hepp, W. : Extracorporeal Shock Wave Lithotripsy. New Aspects in the Treatment of Kidney Stone Disease. 1st. ed. Karger, Basel, Munchen, Paris, London, New York, Tokyo, Sydney, 1982.

17) Bomanji, J., Boddy, S.A.M., Britton, K.E., Nimmon, C.C. and Whitfield, H.N.: Radionuclide evalation pre- and post-extracoporeal shock wave lithotripsy for renal calculi. J. Nucl. Med., 28, 1284-1289, 1987.

18）安河内浩，木下文雄：核医学. 第 5 版，190-211, 医学書院, 東京, 1967.

19）黑須清一, 庵谷尚正, 神部広一, 景山鎮一, 桑原正 明：爆薬を用いた体外腎結石破砕水中衝撃波の生 体に及ぼす影響。日泌尿会誌，78，1252-1259， 1987.

20）吉田修：日本に拈ける尿路結石症の疫学. 日泌 尿会誌，70，975-983，1979.

（1989年11月15日受理） 